Acta vet. scand. $1977,18,416-425$.

From the Department of Animal Husbandry and Genetics, the Department of Internal Medicine I and the Department of Pathology, Veterinary College of Norway, Oslo.

\title{
INDIGESTION IN YOUNG CALVES
}

\section{THE INFLUENCE OF GROUND BARLEY, COARSE AND FINE HAY}

\author{
By \\ B. Laksesvela, P. Slagsvold, N. Krogh, A. Ommundsen and \\ T. Landsverk
}

LAKSESVELA, B., P. SLAGSVOLD, N. KROGH, Å. OMMUNDSEN and T. LANDSVERK: Indigestion in young calves. II. The influence of ground barley, coarse and fine hay. Acta vet. scand. 1977, 18, 416-425. - Four experiments comprising 86 calves have been carried out in order to examine the influence of ground barley, coarse and fine hay, when raising young calves on a high lactose milk replacer causing diarrhoea. The frequency of diarrhoea decreased when feeding barley $(\mathrm{P}<0.01)$ or fine hay $(\mathrm{P}<0.001)$, but increased when feeding coarse hay $(P<0.01)$. Barley increased $(P<0.01)$ live weight gain and carcass weight, reduced $(\mathrm{P}<0.001)$ rumen $\mathrm{pH}$, favoured gram-positive cocci and rods in the rumen, caused hyperkeratosis and gave increased $(P<0.01)$ empty reticulo-rumen weights, the latter being supposed to be enhanced by hyperkeratosis. The calves ate more $(\mathrm{P}<0.001)$ fine than coarse hay, fine hay being superior $(P<0.01)$ in promoting growth of the rumen. All hay maintained a predominantly gramnegative rumen flora, but somewhat different from that on the milk replacer, and counteracted $(\mathrm{P}<0.01)$ low $\mathrm{pH}$ in the rumen and apparently also hyperkeratosis due to barley. The results with barley indicated no relationship between diarrhoea and hyperkeratosis.

b a r le y; hay; indige stion; c alves.

In a previous paper Slagsvold et al. (1977) briefly described the occurrence of indigestion in young calves in Norway, and reported experiments showing that high dietary levels of lactose significantly increased the frequency of diarrhoea. But lactose did not consistently influence intake of hay and barley, growth rate and a number of clinical measurements or anomalies in the digestive tract. In all experiments, the calves received ground barley, chopped hay and tepid water, when they were approx. 3 weeks old. 
According to literature, much barley, and carbohydrates on the whole, may have some undesirable effects in young calves. Thus $\mathrm{pH}$ of the rumen fell on a $90 \%$ barley diet (Fell et al. 1968 ) and on a $87.5 \%$ barley diet (Mullen 1973), but the latter author found that the fall in $\mathrm{pH}$ was partly counteracted by hay. Fell et al. and Kay et al. (1969) also observed that much barley in the diet and low $\mathrm{pH}$ in the rumen content were accompanied by lesions in the rumen wall. It seems, however, that the effect of barley on diarrhoea is open to question.

It is commonly said that young calves should receive fine hay, but it seems difficult to find data from experiments in which coarse and fine hay have been compared.

The present paper describes 4 experiments regarding the influence of ground barley, coarse and fine hay, when raising young calves on a high lactose milk replacer causing diarrhoea.

\section{MATERIALS AND METHODS}

Exps. 1 and 2 were $2 \times 2$ factorial tests of ground barley (GB) and coarse hay ( $\mathrm{CH} 1$ and $\mathrm{CH} 2$ ) as supplements to the milk replacer. Exp. 3, carried out simultaneously with Exp. 2, was a comparison between fine hay (FH 1) and no supplement (NS), while Exp. 4 compared coarse hay ( $\mathrm{CH} \mathrm{3}$ ) and fine hay (FH 2) as single supplements.

The present experiments were conducted in the same manner as those described earlier (Slagsvold et al. 1977), except that specimens for histologic examination were only taken from the central part of atrium ruminis. The recording of the width of the papillae in Exp. 4 was performed by measuring the papillae under the stereomicroscope. The high lactose milk replacer given to all groups was the one denominated $I$ in the previous publication, consisting of $41.4 \%$ skim milk powder, $14 \%$ sweet whey powder, $30 \%$ lactose, $13.3 \%$ butter plus minerals and vitamins. The barley was of normal quality, with $12-13 \%$ total protein and 5-5.5\% crude fibres in the dry matter.

Age and weight of the calves varied from 2 to 13 days and from 29 to $54 \mathrm{~kg}$, respectively, averages being 6-7 days and approx. $40 \mathrm{~kg}$ at the start of the experiments. The number of calves and duration of the tests are set out in Table 2. In Exp. 1, the calves were kept on a concrete floor covered with sawdust, in Exps. 2-4 on raised metal grates with no litter. 
T a b l e 1. Chemical composition of hay used. (CH 1, CH 2 and $\mathrm{CH} 3$ denominate 3 coarse and FH 1 and FH 2 denominate 2 fine samples).

\begin{tabular}{|c|c|c|c|c|c|c|}
\hline & & \multicolumn{3}{|c|}{ Coarse } & \multicolumn{2}{|c|}{ Fine } \\
\hline & & $\begin{array}{ll}\text { CH } 1 \\
\end{array}$ & $\mathrm{CH} 2$ & $\mathrm{CH} 3$ & FH 1 & FH 2 \\
\hline \multirow{5}{*}{$\begin{array}{l}\text { Crude protein, } \\
\text { Fat } \\
\text { N-free extract. } \\
\text { Crude fibres } \\
\text { Ash }\end{array}$} & $\%$ & 8.0 & 6.4 & 6.5 & 10.5 & 12.5 \\
\hline & , & 2.1 & 2.1 & 2.0 & 2.6 & 3.0 \\
\hline & , & 52.7 & 54.6 & 55.7 & 52.1 & 50.2 \\
\hline & " & 31.9 & 32.5 & 31.5 & 28.6 & 26.6 \\
\hline & " & 5.3 & 4.4 & 4.3 & 6.2 & 7.7 \\
\hline Total & „, & 100.0 & 100.0 & 100.0 & 100.0 & 100.0 \\
\hline
\end{tabular}

\section{Hay quality}

All hay samples consisted mainly of timothy, but came from different batches. Their chemical composition is listed in Table 1. CH 3 and FH 2 were also characterized by sorting them meticulously by hand in stem, ears and leaves. FH 2 was grown in a mountain valley, cut at a very early stage and dried artificially; it consisted of $26.7 \%$ stem, $7.3 \%$ ears and $66.0 \%$ leaves. $\mathrm{CH} 3$ was grown on low land, cut at a late stage and dried on wire fences; it consisted of $57.7 \%$ stem, $11.8 \%$ ears and $30.5 \%$ leaves.

\section{RESULTS}

Growth data, feed intake, diarrhoea and general health

Data on the above-mentioned parameters are collected in Table 2, significant differences mainly being pointed out below.

The live weight gain was greater $(\mathrm{P}<0.001)$ on $\mathrm{GB}+\mathrm{CH}$ than on NS in both Exp. 1 and 2, and also when comparing $\mathrm{GB}+\mathrm{CH}$ to $\mathrm{CH}$ and $\mathrm{GB}$ to $\mathrm{CH}(\mathrm{P}<0.05$ in Exp. 1 and $\mathrm{P}<0.01$ in Exp. 2 in both comparisons). In Exp. 3, the weight gain was greater on $\mathrm{FH}(\mathrm{P}<0.01)$ than on $\mathrm{NS}$.

The dressing-out \% was lower $(\mathrm{P}<0.001)$, when relating both types of $\mathrm{CH}$ and $\mathrm{FH}$ to NS, while the differences between $\mathrm{CH}$ and $\mathrm{GB}$ did not reach significance $(\mathrm{P}<0.1)$.

The carcass weights were heavier on $\mathrm{GB}+\mathrm{CH}$, and on $\mathrm{GB}$ than on NS or $\mathrm{CH}$ ( $\mathrm{P}$ values ranging between 0.001 and 0.05 ).

The intake of hay was higher $(\mathrm{P}<0.01)$ in Exps. 1 and 2 when no GB was offered. For the intake of GB, there was no 
Table 2. Duration of the experiments, growth data, average daily intake of ground barley (GB), coarse hay ( $\mathrm{CH})$, fine hay (FH) and electrolyte fluid (EF) and days with diarrhoea.

\begin{tabular}{|c|c|c|c|c|c|c|c|c|c|c|}
\hline \multirow[b]{2}{*}{$\begin{array}{l}\text { Exp. } \\
\text { no. }\end{array}$} & \multirow[b]{2}{*}{ Diet } & \multirow{2}{*}{$\begin{array}{l}\text { Number } \\
\text { of calves } \\
\text { per group }\end{array}$} & \multirow{2}{*}{$\begin{array}{c}\text { Days } \\
\text { on } \\
\text { exp. }\end{array}$} & \multirow{2}{*}{$\begin{array}{c}\text { Wt. } \\
\text { gain } \\
\mathrm{kg}\end{array}$} & \multirow[b]{2}{*}{$\begin{array}{c}\text { Dress. } \\
\%\end{array}$} & \multirow[b]{2}{*}{$\begin{array}{c}\text { Carcass } \\
\text { wt. kg }\end{array}$} & \multicolumn{3}{|c|}{ Daily intake } & \multirow[b]{2}{*}{$\begin{array}{c}\text { Diarrhoea } \\
\text { days }\end{array}$} \\
\hline & & & & & & & $\begin{array}{c}\mathbf{G B} \\
\mathbf{g}\end{array}$ & $\begin{array}{c}\text { hay } \\
\text { g }\end{array}$ & $\begin{array}{c}\mathrm{EF} \\
1\end{array}$ & \\
\hline \multirow[t]{4}{*}{1} & $\mathrm{~GB}+\mathrm{CH} 1$ & 6 & 49 & 22.3 & 49.5 & 31.2 & 454 & 119 & & 14.3 \\
\hline & GB & 6 & 49 & 18.6 & 50.2 & 29.8 & 402 & - & & 5.8 \\
\hline & CH 1 & 6 & 49 & 16.4 & 47.9 & 27.5 & - & 320 & & 19.7 \\
\hline & NS & 6 & 49 & 12.8 & 51.3 & 27.5 & - & - & & 10.8 \\
\hline \multirow[t]{4}{*}{2} & $\mathrm{~GB}+\mathrm{CH} 2$ & 8 & 44 & 19.8 & 53.7 & 33.2 & 170 & 179 & 3.4 & 4.9 \\
\hline & GB & 8 & 44 & 19.4 & 52.8 & 32.4 & 319 & - & 3.7 & 7.5 \\
\hline & $\mathrm{CH} 2$ & 8 & 44 & 13.8 & 51.4 & 28.7 & - & 312 & 4.6 & 21.1 \\
\hline & NS & 8 & 44 & 11.4 & 54.0 & 29.0 & - & - & 4.2 & 16.1 \\
\hline \multirow[t]{2}{*}{$\mathbf{3}$} & FH 1 & 6 & 48 & 19.2 & 50.5 & 28.8 & - & 196 & 3.4 & 7.7 \\
\hline & NS & 6 & 48 & 12.3 & 55.4 & 27.7 & - & - & 4.4 & 19.8 \\
\hline \multirow[t]{2}{*}{4} & FH 2 & 9 & 49 & 22.6 & 50.8 & 31.7 & - & 493 & 3.1 & 3.7 \\
\hline & $\mathrm{CH} 3$ & 9 & 49 & 20.6 & 51.7 & 31.5 & - & 277 & 3.8 & 10.0 \\
\hline
\end{tabular}

clear trend. In Exp. 4, the calves ate $78 \%$ more of $\mathrm{FH}$ than $\mathrm{CH}$ ( $\mathrm{P}<\mathbf{0 . 0 0 1 )}$.

Electrolyte fluid was drunk in somewhat greater quantities when diarrhoea was frequent, but the difference appeared to be insignificant $(\mathrm{P}>\mathbf{0 . 2})$.

Diarrhoea was less frequent $(\mathrm{P}<0.01)$ on GB than on NS when treating Exps. 1 and 2 statistically together $(P<0.1$ in Exp. 1 and $P<0.02$ in Exp. 2). Further, GB gave much less diarrhoea $(\mathrm{P}<0.001)$ than $\mathrm{CH}$.

$\mathrm{CH}$ gave more $(\mathrm{P}<0.01)$ and $\mathrm{FH}$ much less diarrhoea $(\mathrm{P}<$ 0.001 ) than NS.

Other differences shown by Table 2 in the various respects were not statistically significant.

No calves died or appeared clinically ill, apart from the occurrence of diarrhoea.

\section{Findings in the rumen fluid}

During the first 2-3 weeks on experiment, the rumen $\mathrm{pH}$ ranged between 6 and 7 in most cases. Values below 6 or above 7 were occasionally recorded in single samples from some calves. 
As a rule, the $\mathrm{pH}$ kept this level the rest of the time in groups on NS or hay.

On the contrary, the rumen $\mathrm{pH}$ showed a marked $(\mathrm{P}<0.001)$ drop in calves fed GB or GB $+\mathrm{CH}$. In groups on these regimens, the average $\mathrm{pH}$ might fall to nearly 5 with single samples as low as 4.6. In calves on $\mathrm{GB}+\mathrm{CH}$, the $\mathrm{pH}$ rose $(\mathrm{P}<0.01)$ to normal values in the 6th week, whereas it remained low throughout the experimental period on GB.

Direct microscopy of rumen samples revealed great variation in the bacterial picture. On NS the flora consisted of a heterogeneous population of mainly gram-negative bacteria. When hay was fed, the flora was still dominated by gram-negative organisms, although morphologically somewhat different from that on milk feeding. In contrast to these findings, a gram-positive flora of cocci and rods appeared in abundance on GB.

Ciliates were never observed in any of the samples during the experiments, whereas flagellates were regularly found as long as the rumen $\mathrm{pH}$ kept a level of about 6 or higher. Irrespective of the diet, living flagellates were not seen at lower $\mathrm{pH}$.

Similar to the earlier experiments, the gross appearance of the rumen fluid varied considerably. Many samples contained more or less milk products and sometimes also clots of these. Samples with low $\mathrm{pH}$ might be identified by a slightly sourish odour, otherwise the smell varied from aromatic to unpleasant.

\section{Post-slaughter findings in the digestive tract}

Data from the post-slaughter examinations are recorded in Table 3.

Rumen content varied with the diets used. On GB and NS a marked admixture of hairs was noticed. Bezoars were frequent in the rumen of calves on NS; in Exp. 1 their stomachs also contained sawdust. Calves fed FH 2 had a green coloured, fine textured roughage in the rumen, while those fed $\mathrm{CH} 3$ had a coarser, yellow coloured roughage.

Weight of the stomach compartments. The following, significant differences may be worth mentioning: The empty reticulo-rumens were heavier $(\mathrm{P}<0.05)$ on $\mathrm{CH} 1$ than on NS in Exp. 1, and heavier $(\mathrm{P}<0.01)$ on $\mathrm{GB}+\mathrm{CH} 2$ and on GB than on $\mathrm{CH} 2$, and also on $\mathrm{CH} 2$ than on NS in Exp. 2, and heavier on FH 2 than on $\mathrm{CH} 3$ in Exp. $4(\mathrm{P}<0.01)$. When the empty reti- 


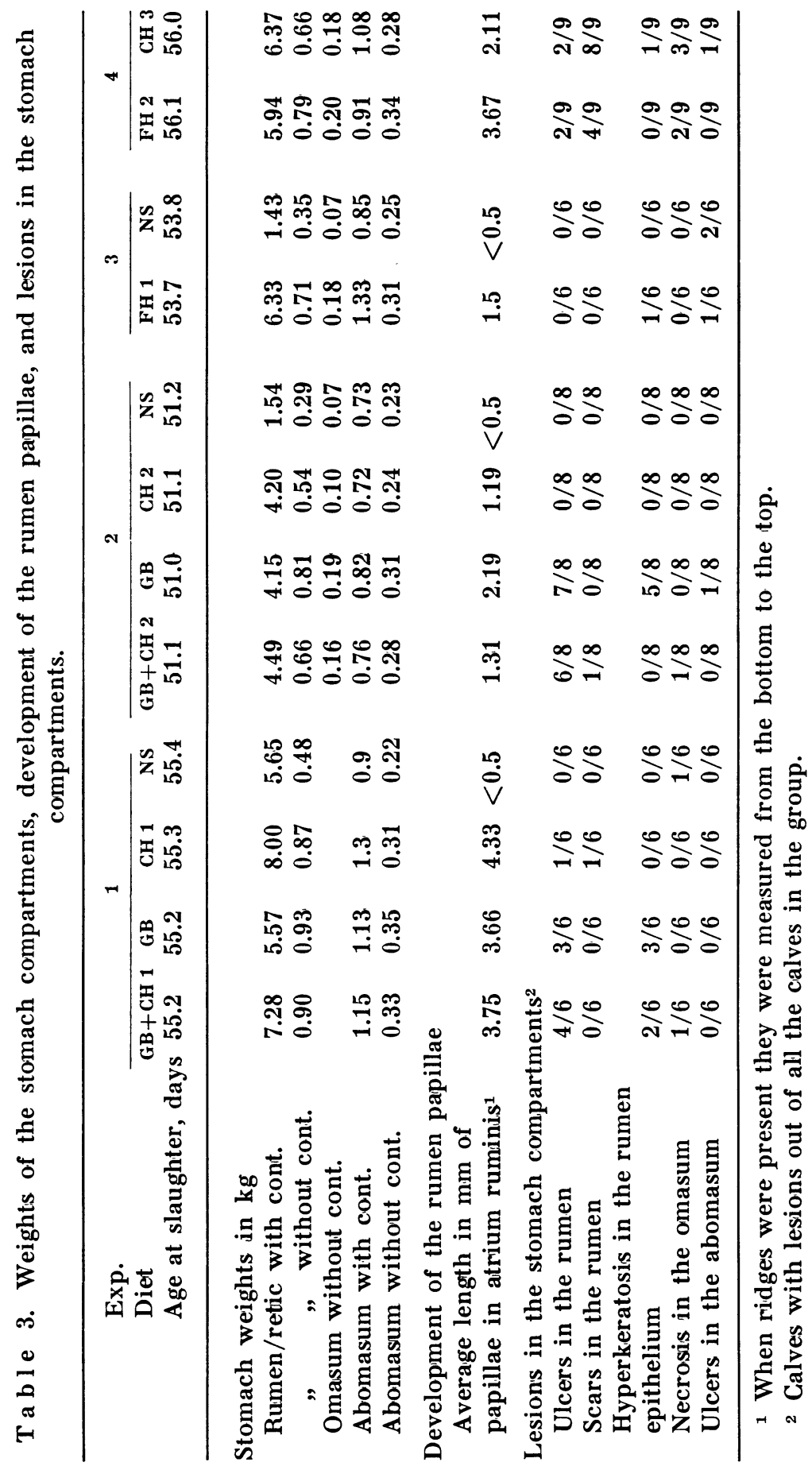


culo-rumen weights in Exp. 2 were corrected for differences in live weights for each calf, the above-mentioned difference between $\mathrm{GB}+\mathrm{CH} 2$ and $\mathrm{CH} 2$ was almost abolished, while the other differences retained their significance. But with this correction the weights on GB appeared significantly higher $(\mathrm{P}<$ 0.01 ) than on $\mathbf{G B}+\mathbf{C H} 2$.

The rumen papillae development. NS gave under-developed papillae, whereas the feeding of hay and barley resulted in papillary proliferation. Extensive hyperkeratosis was noted on barley diets. FH 2 gave longer papillae than $\mathrm{CH} 3(\mathrm{P}<0.01)$. The papillae on FH 2 seemed to be more foliated than on $\mathrm{CH} \mathrm{3}$, the greatest width of the papillae averaging $1.4 \mathrm{~mm}$ on FH 2 versus $1.0 \mathrm{~mm}$ on $\mathrm{CH} 3$. However, the difference was not significant $(\mathrm{P}>0.05)$. Detailed morphological descriptions of the ruminal papillae in selected parts of these experiments will be given in a separate paper.

Ruminal ulcers and scars were more frequent on barley diets and mainly confined to the anterior and posterior rumen pilae. The ulcers were relatively deep and had raised edges. They were elongated with sizes mostly varying from 1 to $10 \mathrm{~cm}$ in length. The omasal necroses in Exps. 1 and 2 were round, up to $2 \mathrm{~cm}$ in diameter, and usually situated in the middle of the laminae. Their colour was dark brown and they were always perforating laminae. In Exp. 4 the omasal necroses were elongated, never more than $3 \mathrm{~mm}$ in length and situated at the border of the laminae. The ulcers of abomasum were usually shallow and round, never more than $15 \mathrm{~mm}$ in diameter, and situated mostly in the pyloric region. Occasionally, petechial haemorrhages were found in the mucosa of different parts of the abomasum.

other organs. No lesions were found outside the digestive tract.

\section{DISCUSSION}

Influence of barley

The experiments reported here showed that ground barley, apart from promoting the growth, counteracted diarrhoea occurring on a high lactose diet. Available publications on the feeding of barley to young calves lack information regarding its influence on diarrhoea.

Regarding reduction in $\mathrm{pH}$, occurrence of hyperkeratosis and ulcers in the rumen following the feeding of much barley, the 
experiments recorded here confirmed the findings of other authors, quoted introductory. The results with barley indicated no relationship between diarrhoea and hyperkeratosis.

Also the findings of hair-admixture in the rumen contents and heavier rumens of calves fed barley in addition to the milk replacer, are in accordance with other reports (Fell et al. 1968, Kay et al. 1969). It is also documented earlier that giving no dry feed leads to under-developed rumen and that supply of hay initiates rumen development, including growth of papillae (Brownlee 1956, Warner et al. 1956, Sandler et al. 1959, Tamate et al. 1962).

\section{Influence of coarse versus fine hay}

The texture of the hay, and qualities that go with it, seemed to be of paramount importance. Fine hay reduced the frequency of diarrhoea and increased the growth of the rumen, including its papillae, compared with coarse hay. Brownlee comparing grass to hay (quality not mentioned), found best development of the rumen papillae with grass.

The fact that the daily intake of fine hay was nearly double the intake of coarse hay may partially explain the better papillae development noted in the calves fed fine hay. Also the nutritive value of the fine hay was assumed to be greater than that of coarse hay. These 2 factors may have increased the amount of available end products of rumen fermentation from fine hay. Volatile fatty acids constituting such end products are known to initiate rumen mucosal development (Warner et al., Flatt et al. 1958, Tamate et al.).

Roy (1970) states that once the rumen begins to function the incidence of diarrhoea is negligible in calves fed a balanced, dry diet. According to the findings reported in this paper, the effect of hay depends on its texture and quality.

\section{Hay - barley interactions}

When correcting the empty reticulo-rumen weights for differences in the live weights of the calves, it emerged that barley gave heavier reticulo-rumens than barley plus hay. This may partly be due to the fact that the feeding of barley was accompanied by hyperkeratosis, while hay was not. These results seem to coincide with the finding of Kay et al. that calves on a barley 
diet had a reduced ratio of rumen muscular to mucosal weight.

It is of interest that hay maintained a predominantly gramnegative rumen flora, similar to that on the milk replacer, and counteracted low $\mathrm{pH}$ in the rumen after a few weeks, and apparently also hyperkeratosis due to barley. The rise in $\mathrm{pH}$ when feeding hay is in conformance with the finding of Mullen (1973), and it is supposed to have prevented hyperkeratosis in the present experiments. Kay et al. showed that raising rumen $\mathrm{pH}$ by the aid of neutralizing salts prevented hyperkeratosis.

\section{CONCLUCIONS}

Ground barley increased the live and carcass weights and counteracted diarrhoea, but reduced rumen $\mathrm{pH}$, favoured grampositive cocci and rods in the rumen, caused hyperkeratosis and increased the empty reticulo-rumen weights.

Fine hay counteracted diarrhoea, maintained a normal $\mathrm{pH}$ and a predominantly gram-negative flora in the rumen, and was superior in promoting growth of the rumen.

Coarse hay aggravated diarrhoea, but counteracted low $\mathrm{pH}$ in the rumen after a few weeks when fed along with barley.

\section{ACKNOWLEDGEMENTS}

We wish to thank the Agricultural Research Council of Norway for financial aid, Peter Møller $\mathrm{A} / \mathrm{S}$ for lending us facilities for 1 experiment and providing most of the ingredients used in the milk replacer, Wessels Kabelfabrikk A/S for providing the fine hay FH 2, and The Government's Agricultural Control Station, Moss, for analysing the feedstuffs.

\section{REFERENCES}

Brownlee, A.: The development of rumen papillae in cattle fed on different diets. Brit. vet. J. 1956, 112, 369-375.

Fell, B. F., M. Kay, F. G. Whitelaw \& R. Boyne: Observations on the development of ruminal lesions in calves fed on barley. Res. vet. Sci. 1968, 9, 458-466.

Flatt, W. P., R. G. Warner \& J. K. Loosli: Influence of purified materials on the development of the ruminant stomach. J. Dairy Sci. 1958, 41, 1593-1600.

Kay, M., B. F. Fell \& R. Boyne: The relationship between the acidity of the rumen contents and rumenitis in calves fed on barley. Res. vet. Sci. 1969, 10, 181-187. 
Mullen, $P$. A.: Rumen liquor $\mathrm{pH}$, osmolality and volatile fatty acid changes in calves fed intensively on barley with hay added. Brit. vet. J. 1973, 129, 267-276.

Roy, J. H. B.: The Calf; Nutrition and Health. Vol. 2, p. 7-8, Iliffe Books Ltd., London 1970.

Sandler, E. G., R. G. Warner, H. N. Harrison \& J. K. Loosli: The stimulatory effect of sodium butyrate and sodium propionate on the development of rumen mucosa in the young calf. J. Dairy Sci. 1959, 42, 1600-1605.

Slagsvold, P., B. Laksesvela, K. Flatlandsmo, N. Krogh, T. L. Ulstein, $N$. Ek \& T. Landsverk: Indigestion in young calves. 1. Different lactose levels in milk diets and milk replacers. Acta vet. scand. 1977, 18, 194-209.

Tamate, H., A. D. McGilliard, N. L. Jacobson \& R. Getty: Effect of various dietaries on the anatomical development of the stomach in the calf. J. Dairy Sci. 1962, 45, 408-420.

Warner, R. G., W. P. Flatt \& J. K. Loosli: Dietary factors influencing the development of the ruminant stomach. Agric. Food Chem. 1956, 4, 788-792.

\section{SAMMENDRAG}

Indigestion hos unge kalver. II. Virkningen av byggrøpp, grovt og fint $h \phi y$.

Fire fors $\varnothing k$ med $i$ alt 86 kalver har vært utført for å undersøke virkningen av byggrøpp, grovt og fint høy når unge kalver ble gitt en laktoserik mjølkeerstatning som forårsaker diaré.

Hyppigheten av diaré minket når det ble gitt byggrøpp $(\mathrm{P}<0,01)$ eller fint høy $(P<0,001)$, men $\varnothing$ kte når det ble gitt grovt $h \emptyset y$ ( $P<$ $0,01)$. Byggr $\varnothing$ pp $\varnothing$ kte $(P<0,01)$ levendevekt og slaktevekt, reduserte $(\mathrm{P}<0,001) \mathrm{pH}$ i vomma og fremmet oppvekst av gram-positive kokker og staver $\mathrm{i}$ vomma, ga hyperkeratose og $\varnothing \mathrm{kt}(\mathrm{P}<0,01)$ vekt av nettmage og vom renset for innhold. Denne vekt $\varnothing$ kningen antas å delvis skyldes hyperkeratose.

Kalvene spiste mer $(P<0,001)$ fint enn grovt $h \varnothing y$, og det fine ga overlegent best vomvekst. Alt $h \phi y$ opprettholdt en overveiende gram-negativ vomflora, som avvek noe fra vomfloraen hos kalver som fikk bare mjølkeerstatning. Høy motvirket etter noen uker den låge pH i vomma, og tilsynelatende også hyperkeratose grunnet byggr $\varnothing$ ppet.

Resultatene med byggrøpp tyder ikke på noen sammenheng mellom diaré og hyperkeratose.

\section{(Received May 18, 1977).}

Reprints may be requested from: B. Laksesvela, Veterinary College of Norway, P.O. Box 8146, Oslo Dep., Oslo 1, Norway. 